\title{
Analysis on Copy Clothing in China
}

\author{
Yuanmei Zhang \\ The Garment College \\ Wuhan Textile University \\ Hubei, China
}

\author{
Hongli Zhang \\ Wuhan institute of design and sciences \\ Hubei, China
}

\begin{abstract}
This paper researches a serious social question about copy clothing in China. First, we analyze the present situation of copy clothing. Second, we analyze the characteristics and the inevitability of copy clothing. We find out the most important element of copy clothing is the relationship between the copy clothing and the original famous brand. Finally, we propose several suggestions to this increasingly serious problem in the Chinese fashion industry.
\end{abstract}

Keywords-copy clothing; intellectual property rights; consumption view; people who make fake products; consumers

\section{INTRODUCTION}

Clothing is "the second skin" of the human body. Clothing, together with human comes from ancient times to today. Especially today, with the rapid development of information technology, more and more famous brands of clothing are emerging under the great efforts of outstanding designers. Clothing and fashion style have also become one symbol of personal success. Most consumers regard it important to wear in famous brand.

So copy clothing has emerged and many famous brands are copied in order to make great profits. This phenomenon harasses the normal market order seriously. Therefore we pose our research topic in view of this social and economic question, and hope that it can arouse more social interest and attention about copy clothing in China.

\section{ANALYSIS ABOUT PRESENT SitUATION AND THE CHARACTERISTICS OF COPY CLOTHING IN CHINA}

\section{A. The Present Situation and Reasons of Copy Clothing in China}

The "copy clothing" mainly means "using fakes to be real products'. It refers to the product pretending to be the real brand product. This behavior is illegal and encroaches upon the copy rights of the original designer and company. People who make copy clothing are order to seek illegal profits through unfair competition.

Many clothing market sells copy clothing in China. When a new style of clothing appears in the market, many similar styles of copy clothing appear in other brands. In addition, the price of this similar clothing is cheaper than the

The Project Supported by Humanities and social science project of Hubei Provincial Education Department (project number: 17Q092), Wuhan textile university research projects "the research about Japanese clothing structure and technology" (school project no.173022). original style. Copy clothing which imitates famous brands is in the "super star" status and sells well in market and networks. Customers are also more likely to buy this copy clothing due to its lower price.

We must pay more attention to the copy clothing of famous brands. More and more consumers who buy copy clothing are young. These people know the truth about copy clothing but they still buy them. The former XiuShui market in Beijing was a central place of copy clothing and many foreigners have gone to this market in the past to buy copies of famous clothing. After the XiuShui market was closed by the government, copy clothing began to appear in a greater number supermarkets and retail stores. They have focused on the younger consumers who have good incomes and jobs. The clothing market in Xiangyang Road in Shanghai was the collection and distribution center of famous copy goods. It was well known by both native and foreign consumers. It was also the fashion market in the mind of many common people. Although this market has now been closed, the producers and sellers of the Xiangyang Road market have move to other places.

Usually before the real clothing is able to sell in the marketplace, it must go through a series of procedures that includes designing, production processing, and product promotion and so on. As for the copy clothing, only through two procedures (design imitation and pattern working) can the products be put on the markets.

The new styles of famous brands regularly have high prices in several hundreds or even several thousands, which cannot be afforded by most common people. Many people like fashionable products, but do not have the financial ability to buy the real famous brand. So this situation requires these consumers to buy the copy clothing for purely economic reasons. It attracts and gives the producers and sellers a chance to produce and sell copy products. Therefore, the copy clothing takes a big share of the markets and in some sense, the copy clothing even sells better than the real design. The copy clothing may sell ten or more while the real sells only one.

\section{B. Characteristics of Copy Clothing}

The copy clothing has a giant market potential and has formed following several obvious characteristics: widespread availability, product expansion and network development. 
1) Widespread availability: Along with the impact of modern science and technology, the people who make the copy clothing have the high technology as well as strong ability. The places where they sell their products have changed from small areas to the large developed cities, from little stores to supermarkets and shopping centers. In addition, consumers have expanded from a former limited number to a much greater number because of the changing of selling places and production technology. So copy clothing has become widespread in both available markets and number of potential consumers.

2) Product expansion: With the gradual development and improvement of society and overall economic conditions, more and more copy clothing is being produced everywhere. People have developed higher and more needs for clothing of all types. Therefore different kinds of things are produced to meet consumers' needs. For example, the kinds of copy products have changed from only fashion clothing to different accessories (hat, scarf, shoes, belt, etc), from fashion clothing to daily life things and so on.

3) The network sell: The network has become new and popular area for the copy clothing enterprises. It is difficult to find and check reality about clothing from network. Because we only find some pictures from network, we can't get the clothing directly. These illegal behaviors and copy clothing have become even more difficult to check today as they have formed a complex, crowded and solid network.

\section{THE SUgGeSTIONS OF SOLUTION}

The copying of clothing, shoes, bags, adornments and female jewelry are obvious and familiar today. Their appearance has its reasons and long history. These reasons include the national situation, individual favor and more. The situation will not disappear in a short time nor disappear easily as long as it meets consumers and social needs. So if we wish to solve the social problem of copying products in China we must do a lot in the following two aspects.

\section{A. We Should Completely Cut the Root of the Copy Things and Forbid Produce of Copy Things}

We must seriously cut root of the copy things. Reports and researches show that 75.2 percent copy products come from some unqualified enterprises. These enterprises only produce copy things in order to earn more benefits and simply neglect basic market principles. Therefore, if we want to research as well as eliminate the copy things, we must pay attention to the unqualified enterprises that have great manufacturing equipment and regular employees, because they have enough ability to produce products quickly and have good sales markets as well as targeted consumers.

\section{B. Clothes Enterprises Should Adjust the Management Tactics and Strengthen Their own Design Capacity in China}

The basic reason of pirate appearance in clothes enterprises lies in that the style design is not good in Chinese company. Chinese dress designing level stays far behind in the world. Numerous enterprises rely mainly on copy. It is very difficult to form one's own products style. In addition, domestic clothes enterprises are short of complete design and train mechanism. So, if clothes industry wants to get greater development in the future, they should strengthen their own designing capacity and realize industry upgrading.

\section{Improving Consumer Consciousness about Consumption}

Strictly saying, the copy goods are treated differently in China and in foreign countries. We must say "NO" to copy things. A true report said that an old couple of Danish who had spent 10 Euro to buy "a pair of famous brand eyeglasses". After buying the eyeglasses, they experienced an unforgettable matter. The local examiner stared at them and confirmed the old couple's behavior. Then they told the couple they bought a pair of copy famous brand eyeglasses and immediately showed the Italian new promulgation law. According to the Italian new promulgation law, people who buy the copy goods must be punished with high fines. Finally these two old people had to pay 3000 Euro fines. Comparing with the sanction of the buyer in Italy, it is obviously tolerant for the coping goods buyers in China, because the punishment frequently falls upon the copy producer and seller, not upon the buyers. We treat buyers extremely tolerant in domestic country. Consumers are 'the copy products soil' and the final owner. If we want to eradicate the copy products, we must make consumers have strong awareness about brand rights and sense of responsibility. We cannot make China become "the heaven" of the copy goods.

\section{CONCLUSION}

Some experts say that people who always buy the copy brand products are just like those people who smoke and drink as they will become addicted, because most people are willing to spend little money to buy the 'famous brand' products for their vanity without any penalty. As for harming regular benefit of enterprise, reducing consumption level and destructing market order is not the important things to these consumers. However, they did not consider if they buy the copy things regularly, their aesthetic level and public moral awareness will become less and superficial. Their behaviors are harmful to our society and country. Finally we cannot buy the best quality goods in future as they may become less and less available. Everybody must raise his or her own consciousness and resist the copy products together. If we do so "this wild flower," the copy product, will lose its 'fragrance' gradually, and finally 'wither' without consumer watering.

Some people summarize the clothing profession in such words as 'labor intensive', 'the community development' and 'pirates', among which the last one is the old ailment of the Chinese clothing profession. The clothing "pirates" have become a common phenomenon which has truly harassed the market order. The "pirates" enterprise has become the aim of numerous arrows, but we must objectively find the weakness of these "pirate" enterprise's, as well as government's insufficiency in copy rights' protection. The Chinese Clothing Enterprise's development is going along with 
reforms and open policy. The economic growth is going on, technical skills are increasing, labor intensive manufacturing is lessening, while the regulations of intellectual property rights remains seriously insufficient. It takes a long time to change this situation. It's urgent for the government to take measures to encourage independent innovation and promote copy rights protection.

Certainly, the most essential link is to stop the behaviors of producing and buying the copy clothing. If the clothing enterprise adjusts the management strategy, strengthens its own designing capacity and enhancing consumers' expense consciousness, the Chinese apparel industry's problem of the copy clothing will be solved easily and the step of original Chinese clothing will advance to the international stage at a stride.

\section{REFERENCES}

[1] Guo Yan. China textile clothing industry after quota age [M]. Beijing: China's textile press. 2007.1.

[2] Liu Jiali. Clothing enterprise marketing planning and market competitiveness of actual combat case and famous enterprise classic case analysis [M].Anhui: Anhua audio and video press.2004.3.

[3] Wang Wedi. China coutume culture [M]. Shanghai: Shanghai ancient books press. 2001 .

[4] Zeng Hong. Clothing design [M]. Nanjing: Southeast university press.2006.4. 